\title{
Prospects and Challenges of the Study of Anti-Glycan Antibodies and Microbiota for the Monitoring of Gastrointestinal Cancer
}

\author{
Eugeniy P. Smorodin (ID
}

Citation: Smorodin, E.P. Prospects and Challenges of the Study of Anti-Glycan Antibodies and Microbiota for the Monitoring of Gastrointestinal Cancer. Int. J. Mol. Sci. 2021, 22, 11608. https://doi.org/ $10.3390 /$ ijms 222111608

Academic Editor: Alexander O. Chizhov

Received: 20 September 2021 Accepted: 25 October 2021 Published: 27 October 2021

Publisher's Note: MDPI stays neutral with regard to jurisdictional claims in published maps and institutional affiliations.

Copyright: (C) 2021 by the author. Licensee MDPI, Basel, Switzerland. This article is an open access article distributed under the terms and conditions of the Creative Commons Attribution (CC BY) license (https:// creativecommons.org/licenses/by/ $4.0 /)$.
Department of Virology and Immunology, National Institute for Health Development, 11619 Tallinn, Estonia; jevgeni.smorodin@outlook.com

\begin{abstract}
Over the past decades, a large amount of data has been accumulated in various subfields of glycobiology. However, much clinically relevant data and many tools are still not widely used in medicine. Synthetic glycoconjugates with the known structure of glycans are an accurate tool for the study of glycan-binding proteins. We used polyacrylamide glycoconjugates (PGs) including PGs with tumour-associated glycans (TAGs) in immunoassays to assess the prognostic potential of the serum level of anti-glycan antibodies (AG Abs) in gastrointestinal cancer patients and found an association of AG Abs with survival. The specificity of affinity-isolated AG Abs was investigated using synthetic and natural glycoconjugates. AG Abs showed mainly a low specificity to tumour-associated and tumour-derived mucins; therefore, the protective role of the examined circulating AG Abs against cancer remains a challenge. In this review, our findings are analysed and discussed in the context of the contribution of bacteria to the AG Abs stimulus and cancer progression. Examples of the influence of pathogenic bacteria colonising tumours on cancer progression and patient survival through mechanisms of interaction with tumours and dysregulated immune response are considered. The possibilities and problems of the integrative study of AG Abs and the microbiome using highperformance technologies are discussed.
\end{abstract}

Keywords: glycoconjugates; antibodies; cancer; survival; prognosis; tumour microbiota

\section{Introduction}

Simple and complex carbohydrates (glycans, glycoconjugates) play a vital role in organisms. Glycans are targets for the recognition of self and foreign antigens by the immune system, and microorganisms use host glycans for their adhesion and further colonisation. The biological role and numerous functions of glycans have been well presented by Ajit Varki [1]. Abnormal structures of glycans are expressed in cancer that are promising biomarkers and targets for therapy. However, changes in the glycosylation pattern make the tumour cells evade immunosurveillance [2]. In this respect, the role of anti-glycan antibodies (AG Abs) in the mechanisms of anticancer defence remains unclear.

The repertoire of the circulating AG Abs in healthy individuals is relatively unique and stable, which makes it possible to monitor changes of the protective Abs in diseases [3]. The profile of AG Abs depends on contacts with environmental factors and past illnesses and represents Abs against foreign antigens and auto-Abs, including Abs that bind to tumour-associated glycans (TAGs) [4]. The circulating auto-Abs to TAGs might protect against cancer; however, their protective role and association with cancer progression remain poorly understood. We undertook the follow-up study of gastric and colorectal cancer (CRC) patients and used an enzyme-linked immunosorbent assay (ELISA) with polyacrylamide glycoconjugates (PGs) to monitor the levels of IgG Abs reactive to tumour-associated Thomsen-Friedenreich (TF) and its precursor (Tn), and other glycans to assess the association of the AG Abs level with survival and clinical parameters. The increased attention to these TAGs and respective Abs is due to their expression in ma- 
lignant tumours; the relation to differentiation, invasiveness, and metastasis; as well as the potential for diagnostics, prognosis, and immunotherapy [2,5-8]. The expression of the so-called Thomsen-Friedenreich (TF) on red blood cells after treatment with bacterial neuraminidases was described by Thomsen and specified by Friedenreich [9]. In basic research by the G. Springer group, TF (in their abbreviation " $\mathrm{T}$ ") and Tn have been described as immunoreactive pancarcinoma antigens that are often expressed in tumours but are usually hidden and inaccessible to the immune system in normal tissues $[10,11]$. Furthermore, we studied the specificity of AG Abs isolated from the serum of long-term survivors. This paper analyses the research results and discusses the possibilities and challenges of an integrative approach to the study of AG Abs and pathogenic bacteria colonising tumours and their involvement in the progression of cancer and dysregulation of the immune response in the tumour microenvironment.

\section{Association of the Level of AG Abs with Survival}

The discovery of TAGs markers, such as CA 19-9 and CA 72-4, which are overexpressed in cancer cells and tumour samples and appear in the bloodstream, contributed to their widespread use in clinical oncology for diagnostic and prognostic purposes [12]. To the best of our knowledge, over the past decades, many works on diagnostic and predictive studies of TAGs have been published [13-15]. Glycan-specific antibodies are also represented in the literature as potential biomarkers for cancer diagnosis $[16,17]$. However, the relationship between AG Abs and prognosis of cancer patients remains poorly understood. A Search on PubMed, Web of Science, Scopus, and Crossref found only one noteworthy clinical investigation, i.e., the observation of patients with cervical cancer over a long period. The authors note that the presence of IgG AG Abs in sera was associated with better survival and treatment modalities [18]. We studied the level of IgG Abs that are reactive to TAGs, namely anti-TF $\alpha,-\mathrm{Tn}$, and cancer-irrelevant xenoreactive anti- $\alpha \mathrm{Gal}$, as well as anti-GalNAc $\beta$ and $-\mathrm{PF}_{\mathrm{di}}$ (structures shown in Table 1), in the sera of patients with gastric, colorectal, and breast cancer [8,19-22]. The preoperative level of Abs, its postoperative changes during a long-term follow-up, relation to survival, and clinical parameters were investigated $[20,21]$. A significantly better survival rate was observed in gastrointestinal cancer patients with an increased level of anti-TF, -Tn, and -GalNAc $\beta$ Abs, whereas a significantly worse survival rate was observed in groups with an increased level of anti- $\alpha \mathrm{Gal}$ Abs (Figure 1). The increased anti-PF ${ }_{\mathrm{di}} \operatorname{IgG}$ level was associated with the stages of gastric cancer, but no significant difference in survival rate was found $[21,23]$.

Table 1. Twofold or more changes of the AG Abs level in the monitoring of gastrointestinal cancer patients (presented for the first time).

\begin{tabular}{|c|c|c|c|c|}
\hline AG IgGs & Total $n$ cases & Increase $\geq 2, n$ & Decrease $\geq 2, n$ & Change in $\%$ \\
\hline TF (Gal $\beta 1-3 G a l N A c \alpha)$ & 109 & 8 & 3 & 10 \\
\hline $\operatorname{Tn}($ GalNAc $\alpha)$ & 109 & 8 & 7 & 14 \\
\hline$\alpha \mathrm{Gal}(\mathrm{Gal} \alpha 1-3 \mathrm{Gal} \beta)$ & 109 & 12 & 18 & 28 \\
\hline GalNAc $\beta$ & 85 & 1 & 1 & 2 \\
\hline$P_{\text {di }}($ GalNAc $\beta 1-3$ GalNAc $\beta)$ & 85 & 7 & 8 & 14 \\
\hline
\end{tabular}

The benefit from a higher level of anti-TF Abs in relation to survival might be explained through possible involvement of Abs in the inhibition of metastasis-promoting interaction of TF-MUC1 with galectins for circulating tumour cells. TF-MUC1 contributes to galectinmediated adhesion of cancer cells to blood vascular endothelium. The increased level of circulating galectin- 2 is correlated with a significantly increased mortality in patients with colorectal cancer (CRC). However, this association was not observed in patients with a high level of auto-Abs against TF-glycosylated MUC1 [24]. The role of galectins in cancer progression, including prognostic assessment in meta-analyses, has been published [25]. 
In addition to TF, another galectin 3 ligand, namely, the Lac-di-NAc glycan (GalNAc $\beta 1$ 4GlcNAc), is also considered a TAG [26-28]. The role of interaction of Lac-di-NAc with galectin-3 in the context of circulating Abs in cancer progression remains unexplored.
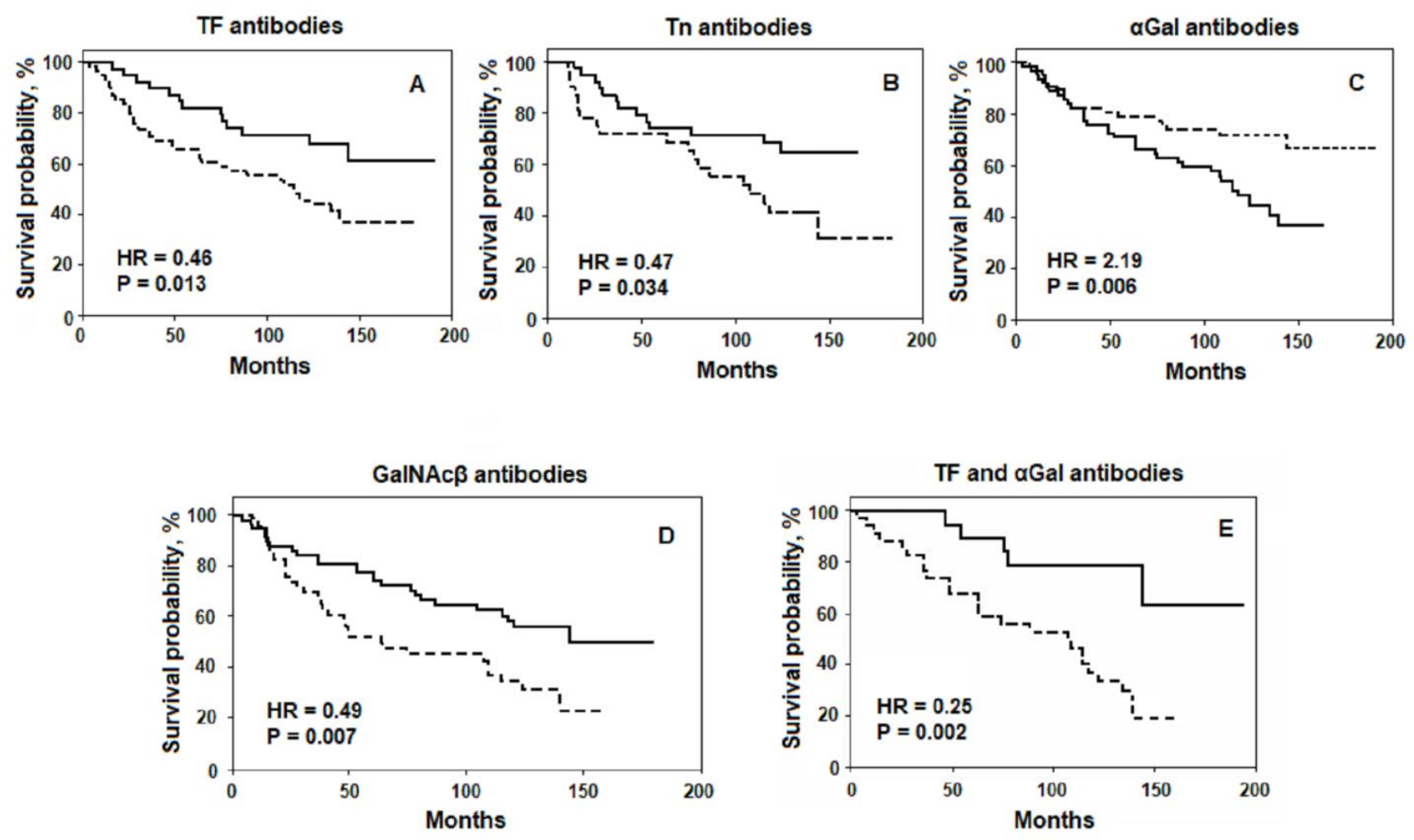

Figure 1. The relation of the preoperative AG Abs level to the survival rate of patients with gastrointestinal cancer. Solid line: level of serum AG Abs above or equal to the median; dashed line: the level below the median. (A,C) all patients; (B) patients with well and moderately differentiated G1-2 tumours; (D) patients with T2-4 size of the primary tumours. (E) the probability of survival assessed by two parameters: patients with increased anti-TF and decreased anti- $\alpha \mathrm{Gal}$ Abs level (solid line) vs. patients with decreased anti-TF and increased anti- $\alpha \mathrm{Gal}$ Abs level (dashed line). HR: hazard ratio. Adapted from $[20,21]$. (Under Creative Commons Act License).

The level of AG IgGs did not undergo major changes in most patients, but we observed more than a two-fold increase or decrease of Abs in dynamics (Table 1) $[20,23,29,30]$. A high level of anti-TF IgG was observed in $6 \%$ of long-term survivors, and among them, the survival rate exceeding 15 years was noted in stage III of gastrointestinal cancer. The increase of the anti-TF IgG level was noted after surgery, blood transfusion, influenza, and prolonged adjuvant chemotherapy. In the latter case, up to a 12 -fold increase from the initial low background level was noted. Similarly to anti-TF IgG, the levels of anti-Tn and $\alpha \mathrm{Gal}$ IgG were increased after surgery or chemotherapy in some patients and remained elevated or returned to baseline values. This may be explained by the paradigm of gut microbiota involvement in AG Abs formation, which is discussed in Section 5, since both radical surgery and chemotherapy affect the gut microbiota [31].

The low preoperative level of anti-TF IgG remained low after surgery was performed on patients with metastatic cancer and prevailed in patients with poorly differentiated G3 tumours. On the contrary, an increased anti- $\alpha \mathrm{Gal}$ IgG level was related to advanced cancer $[20,29,32]$. According to a study by Springer et al., surgery leads to an increase of anti-TF antibody titres in breast cancer patients [33]. The level of anti-TF IgG was correlated with the number of lymphocytes in the blood and was inversely correlated with the ratio of neutrophils/lymphocytes [20,29]. We also observed an association of the AG Abs level with clinical manifestations and its changes in patients with chronic hepatitis C [34]. Overall, 
these observations may be a sign of an adaptive AG IgG antibody response in individual patients with digestive tract pathology.

\section{Prognostic Potential of AG Abs}

The relationship between the preoperative level of AG Abs and its dynamics with the survival rate, tumour stage, and grading are noteworthy regarding prognostication. The combined determination of two independent anti-TF and $-\alpha \mathrm{Gal}$ Abs levels is more informative and can increase the prognostic potential (Figure 1E). The association with survival has been shown by the commonly used ELISA method with synthetic PGs. The glycan microarrays are a powerful tool for bioinformatics, enabling simultaneous detection of the Abs binding with a large set of glycans in a single format $[4,35]$. The diagnostic and prognostic potential of printed and suspension glycan arrays has been demonstrated for ovarian cancer, which may be a useful adjunct to the commonly used tumour marker CA125 [36,37]. Arrays enable the finding and selection of suitable glycans and also exploration of their optimal combinations to increase the predictive potential of AG Abs in cancer.

\section{Study of the AG Abs Specificity}

The heterogeneity and wide variety of natural glycans are challenges when studying the specificity of AG Abs. Synthetic glycoconjugates with known structure, conformation, and spatial orientation, and the density of glycotopes are a precision tool in the study of glycan-binding proteins; therefore, they could be adapted for different aims in glycobiology and medicine. PGs and adequate controls have demonstrated good reproducibility, low background, and better discrimination between comparable parameters in ELISA. Homogeneous PG models enable the detection of glycotope-specific Abs [38]; therefore, they have certain advantages over natural antigens containing different determinants.

To study the AG Abs specificity, Abs were affinity isolated from sera of patients with cancer using glycans bound to carriers. In general, AG IgGs in the indirect and competitive ELISA showed either the reactivity restricted by the key glycan used for isolation or crossreactivity to similar glycans, and no polyreactivity towards irrelevant antigens [39-41] (peculiarities are discussed in [42]). Anti-TF IgG populations were isolated from the sera of long-term gastrointestinal cancer survivors. Abs varied in the reactivity and cross-reactivity to synthetic TF-related conjugates. In the majority of samples, the Abs were more specific to $\mathrm{TF} \beta$ (Gal $\beta 1-3 \mathrm{GalNAc} \beta$ ) than TF $\alpha$, and the terminal Gal $\beta$ residue was essential for antibody binding $[39,41]$. Affinity-isolated Abs were able to bind to natural antigens, such as asialoglycophorin and GA1 glycosphingolipid (anti-TF populations), glycosphingolipids isolated from pig kidney or rabbit erythrocytes (anti- $\alpha \mathrm{Gal} \operatorname{IgG}$ ), and $\mathrm{A}_{\mathrm{di}} / \mathrm{A}_{\text {tri }}$ cross-reactive IgGs agglutinated human A-blood group erythrocytes [39-43]. The binding of $\alpha \mathrm{Gal}$-reactive Abs to glycosphingolipids depends on the avidity of Abs. For example, anti- $\alpha \mathrm{Gal}$ IgG with high avidity for $\mathrm{B}_{\mathrm{di}}-\mathrm{PG}$ binds to rabbit erythrocyte glycosphingolipids, similar to monoclonal Abs Gal-13, while cross-reactive anti- $A_{\mathrm{di}}$ IgG with lower avidity for $\mathrm{B}_{\mathrm{di}}-\mathrm{PG}$ does not bind [40,44]. The range of $\mathrm{IC}_{50}$ for PGs with isolated Abs was from $2 \times 10^{-8}$ to $7 \times 10^{-6} \mathrm{M}$. These results were obtained by affinity chromatography using a solution of $8 \mathrm{M}$ urea for elution of Abs at lower temperatures $\left(4-10^{\circ} \mathrm{C}\right)$, with gradual removal of urea by dialysis, which may be preferable in order to restore the activity of AG Abs.

Cancer-associated mucins that express TF, Tn, and Sialyl-Tn glycotopes are implicated in immune modulation and metastasis. Poorly glycosylated mucins at the tandem-repeat region can generate cancer-specific immunodominant epitopes, but immunogenicity is abrogated in a higher density of saccharides in MUC-glycopeptides [45]. Possibly, some cancerous sera contain AG auto-Abs that are reactive to truncated glycans of the MUC family or to the TF/Tn glycoforms of IgA1 that are found in sera and tumour samples from breast cancer patients [46,47]. However, mucin-type TAGs appear to not be a target for the studied AG Abs, which can be explained by the presence of cluster glycoforms in the context of the Thr/Ser-peptide core, while AG Abs recognise discrete glycotopes 
in PGs with a glycan density of $10-20 \%$. Anti-TF IgGs did not bind the conjugate of $80 \%$-TF-PG. AG Abs have been found to bind short fragments from larger glycans but do not recognise the same fragment in the context of the whole natural chain [45]. In the competitive ELISA, affinity-purified anti-Tn and -Sialyl-Tn IgGs demonstrated weak or no binding to mucins isolated from malignant breast tumours, ovine submaxillary mucin, and asialo-ovine submaxillary mucin, in comparison with Tn- and Sialyl-Tn-PGs [41]. The binding of anti-TF IgG to mucins from breast cancer specimens was observed in only $14 \%$ of specimens. The binding ability of purified anti-TF and anti-Tn Abs to breast cancer tissues was demonstrated by other authors using an immunohistochemical method [48]. The authors used natural antigens (asialofetuin and ovine submaxillary mucin) and a plasma pool of donors to isolate Abs, resulting in Abs that were able to specifically recognise carcinoma tissues. Apparently, such a method should lead to the isolation of broadly specific Abs populations. We used carriers with the synthetic homogeneous TF $\alpha$-ligand and serum from individual patients to isolate anti-TF Abs. The resulting populations of Abs were heterogeneous and differed in cross-reactivity to glycosphingolipid-related glycans (TF $\beta$, GA1, and Gb5 trisaccharide) and asialo-glycophorin [22,41].

Thus, Abs that are specific to TAGs that were presented in PGs exhibited low specificity in relation to natural tumour-associated and tumour-derived mucins. Anti-TF IgG Abs showed high reactivity to mucins isolated from breast cancer tissue but for rare specimens, which presumably was due to the admixture of bacterial glycoconjugates, since a diverse microbiota can colonise malignant breast tumours [49].

\section{Paradigm of Microbial Origin of AG Abs Stimulus}

Gut microbiota are involved in the formation of AG Abs both in the intestine and in the blood circulation system. The emergence of Abs against self-glycans, including Abs related to autoimmune disorders, is based on the molecular mimicry between bacterial and human glycoconjugates upon stimulation with bacterial antigens [50]. The immunodominant regions and molecular patterns of glycans for many human pathogens remain poorly studied. Mammalian and bacterial glycosyltransferases can synthesise the same glycan linkages; however, there are considerable differences between mammalian and bacterial glycans since the latter are often composed of repeating units and contain carbohydrates and other structures that are irrelevant to mammalian cells. TF and other glycotopes were found in the $\mathrm{O}$ antigens of Gram-negative bacteria [51]. The repeating units in the coaggregation receptor polysaccharides of oral streptococci contain a host-like disaccharide motif, either Gal $\beta 1-3 \mathrm{GalNAc}$ or GalNAc $\beta 1-3 \mathrm{Gal}$, as well as the immunodominant external GalNAc $\alpha$ saccharide [52,53]. In humans, Abs against TF and Tn are produced in response to bacterial antigens [54]. Human natural anti-Tn IgM Abs were able to bind a restricted number of Tn-terminated oligosaccharides better than the parent monosaccharide; however, Abs bound several bacterial polysaccharides that have no structural resemblance to $\mathrm{Tn}$ [55]. True disaccharide $\mathrm{TF} \alpha$ has been identified in the capsular polysaccharide structure of Bacteroides ovatus strains, but, in general, human intestinal bacteria rarely express true $\mathrm{TF} \alpha$ [56]. Mice immunised with B. ovatus in the absence of adjuvants developed specific anti-TF $\alpha \operatorname{IgM}$ and IgG antibodies, which were able to bind TF $\alpha$-carrying human cancer cells. In humans, dietary supplementation of B. xylanisolvens was able to increase the serum level of TF $\alpha$-specific IgM Abs $[57,58]$.

Microbial pathogens may cause changes in the glycosylation profile of mucins. Acute Helicobacter pylori infection can be accompanied by a dramatic but transient loss in mucin oligosaccharides that may promote bacterial colonisation and persistence [59]. TF glycan is expressed in surface membrane glycoconjugates of $H$. pylori. A better survival rate was observed in $H$. pylori seropositive vs. seronegative patients with gastric cancer, especially in those with a high level of anti-TF IgG [60]. According to a recent meta-analysis, H. pylori infection is an indicator of better prognosis in the European population of gastric cancer patients [61]. 
Bacterial glycosidases modify host glycans, thus exposing hidden areas, and thereby may provoke the production of auto-Abs. The TF antigen is usually cryptic, but it is exposed on erythrocytes and renal glomeruli because of the neuraminidase A desialylation in Streptococcus pneumoniae infections [62]. Adhesins of some pathogenic bacteria can bind TF and Tn glycans of the host cells [63,64], which also might be one of the reasons for AG Abs production. It is noteworthy that human circulating IgGs contain specificities of self-glycans that are receptors for viral and bacterial pathogens and/or exotoxins [65].

The $\alpha$ Gal epitope (Gal $\alpha 1-3 G a l \alpha 1-4 G l c N A c-R)$ is not expressed in human cells, but the anti- $\alpha \mathrm{Gal}$ Abs is naturally generated $[66,67]$. Human anti- $\alpha \mathrm{Gal}$ IgG was found to bind Gram-positive and Gram-negative pathogenic bacteria. Cross-reactivity to blood grouprelated glycans was shown for anti- $\alpha \mathrm{Gal}$ IgG and, in general, Abs contain multiple subsets with reactivities beyond terminal $\alpha \mathrm{Gal}$ hapten. These subsets in concert target a wide range of microbial polysaccharides and may contribute to human protective immunity against infections $[40,43,68-70]$. According to our observations, the increased level of anti- $\alpha \mathrm{Gal}$ Abs in patients with cancer is presumably associated with pathogen-mediated chronic inflammation [20].

Although a better survival rate for cancer patients with elevated anti-TF and -Tn IgG levels has been found, an explanation for these observations in terms of a protective immune response against TAGs-expressed cancer cells remains speculative. It is possible that some populations of anti-TAGs auto-Abs can impede tumour progression in individual patients, but to confirm this assumption, personal investigation using autologous samples is required. Solid tumours are typically low auto-immunogenic owing to immunosuppression and adaptation to host immunity. The presence of a certain microbiota in a tumour microenvironment can recruit and activate immune cells [71,72]. The existing relationship between AG Abs and the gastrointestinal microbiota community is worthy of attention. There is a rather indirect relationship between patient survival and the studied AG Abs, mediated by the presence of microorganisms that promote or inhibit cancer progression [73].

\section{Influence of Microbiota on Cancer Progression}

\subsection{Beneficial or Normalising Effects of Bacteria}

The human microbiota is comprised of numerous bacterial genera, which are present in different areas of the body, mainly in the large intestine. The normal functioning of intestinal microbiota maintains immune homeostasis while dysbiosis and impairment of the intestinal barrier are associated with the development of inflammatory disorders, which may lead to cancer [74]. Bacterial microbiota can either inhibit or stimulate carcinogenesis and tumour progression via different mechanisms [75-77]. Opportunistic infections may occur in immunocompromised cancer patients that need antibiotic treatment. Using probiotics including Bifidobacterium and Lactobacillus genera may normalise microbial composition, protect against pathogen-mediated inflammation, and inhibit carcinogenesis [74,78-80]. Perioperative administration of probiotics/synbiotics in gastrointestinal cancer patients may improve the quality of life while reducing postoperative complications, including infection incidence, as was shown in meta-analyses [81,82].

Various tumour-related factors predicting the survival rate after tumour resection have been explored, one of which is tumour-associated microbiota. Prolonged survival may depend on the immunogenicity of tumour neoantigens, which can be recognised by $\mathrm{T}$ cell clones that are cross-reactive to microbial peptide antigens [83]. In patients with pancreatic cancer, the tumour microbiome diversity affects survival. In long-term survivors, the unique intra-tumoural composition of microbiota was identified, which may contribute to a favourable microenvironment that is characterised by the recruitment and activation of CD8 T cells [71]. In CRC patients with a better clinical outcome, tumours were significantly enriched in certain bacterial genera and exhibited a high expression of genes encoding $T$ cell markers and chemokines [72]. 


\subsection{Harmful Effects of Bacteria}

Commensal microorganisms are crucial for the maintenance of local and systemic immune homeostasis, and disbalance of the commensal ecosystem resulting in dysbiosis [74]. Different taxa of tumour-associated microbiota are implicated in cancer pathogenesis and their diagnostic and prognostic potential have been assessed [84]. Dysregulated immune response in the tumour microenvironment and anticancer therapy-mediated systemic immunosuppression may also contribute to the colonisation of pathogens in tumours. Anaerobic bacteria can colonise hypoxic areas of tumours, which can be used for bacteriabased cancer immunotherapy [85]. Opportunistic and pathogenic bacteria propagate in dysbiosis and potentiate tumour progression through chronic inflammation, modulation immune responses, and metabolic and signalling pathways [76,77]. Dysbiosis can increase intestinal permeability and potentiate the translocation of microbial products through the mucosal barrier to the liver, spleen, and bloodstream, thus promoting inflammation, fibrosis, and tumourigenesis $[77,86,87]$.

Some opportunistic and pathogenic bacteria can colonise and predominate in tumour tissues of the gastrointestinal tract compared to adjacent non-tumour or normal tissues, thus boosting tumour development and spread [88]. It has been found that colonisation of enterotoxigenic and pathogenic bacteria is associated with advanced CRC [89]. Two species of oral bacteria, namely, Fusobacterium nucleatum and Porphyromonas gingivalis, are examined in this section as an example, owing to a growing interest in their role in orodigestive cancer pathogenesis and progression [90]. In general, bacteria promote proliferation and invasiveness of cancer cells, angiogenesis in the tumour microenvironment, and induce resistance to apoptosis through different signalling pathways [91]. These oral bacteria are closely related to the promotion of cancer development in regions other than the oral cavity. Although many studies have revealed an association, rather than a causal link, between microbial composition and oncogenesis, the impact of some bacteria on tumour progression deserves special attention.

F. nucleatum belongs to an anaerobic Gram-negative bacterium. It is typically resident in the oropharynx, inhabits other organs, coaggregates with other bacteria species in the oral cavity, and is related to periodontal disease. F. nucleatum is present in colorectal carcinoma tissue and possesses immunosuppressive activity via the mechanism of $\mathrm{T}$ cell response inhibition [92]. The F. nucleatum-enriched tumours of CRC are characterised by increased tumour growth and invasion, and pro-tumoural immune responses [93,94]. Prevailing in the CRC tissues, F. nucleatum is stably maintained in primary tumours and distal metastases. Mouse xenografts of human primary colorectal adenocarcinomas were found to retain viable Fusobacterium and its associated microbiome through successive passages [95]. As was shown by qPCR, Fusobacterial genomic DNA was present in distal metastases, which suggests bacterial tropism to CRC tumours. This can be explained by the evidence for the integration of bacterial DNA into the human somatic genome via intermediate RNA, which was found more often in (a) tumours rather than normal samples, (b) RNA rather than DNA samples, and (c) the mitochondrial genome rather than the nuclear genome [96].

Interestingly, the Fap2 adhesin of F. nucleatum interacts with TF (the peanut agglutininreactive glycan) in CRC specimens. This binding leads to the bacterial enrichment of primary and metastatic TF-overexpressed adenocarcinomas [63]. In mice models, hematogenous F. nucleatum can colonise colorectal and mammary tumours by the mechanism of Fap2-TF interaction, suppress the accumulation of tumour-infiltrating T cells, as well as promote tumour growth and metastatic progression, which can be counteracted by antibiotic treatment. Bacterium-dependent evasion of tumour from immune response may occur by means of the interaction of Fap2 with TIGIT and CEACAM1 receptors, leading to inhibition of $\mathrm{T}$ and NK cell activities [63,97-99]. Outer membrane proteins Fap2 and RadD can induce cell death in human lymphocytes [100]. The immunosuppressive effect of F. nucleatum in the microenvironment of colorectal tumours may be due to the promotion of M2 polarisation of macrophages through a TLR4-dependent mechanism [101]. F. nucleatum 
can adhere to the intestinal epithelium through other surface proteins, inducing inflammation and the recruitment of inflammatory cells, and creating an environment that favours tumour growth [102].

The amount of $F$. nucleatum DNA in the CRC tissue is associated with a shorter survival time and may potentially serve as a prognostic biomarker $[103,104]$. The prognostic potential and relation of F. nucleatum to clinical characteristics of CRC patients was assessed using meta-analysis. Worse overall and cancer-specific survival, as well as tumour growth and distant metastases, were associated with an abundance of F. nucleatum in tumours [105]. F. nucleatum-positive tumours were detected more frequently compared to non-tumourous tissues in gastric cancer patients, and the presence of bacteria in the Lauren classification diffuse type of tumours was associated with significantly worse overall survival [106]. Fusobacterium species status was independently associated with a worse prognosis of patients with pancreatic cancer [107]. It is considered that unfavourable microbiota in the pancreas can influence the tumour microenvironment and induce immune suppression. It is assumed that alterations in the pancreatic microbiota could prolong the survival of patients with pancreatic ductal adenocarcinoma and improve the response to immunotherapy and chemotherapy $[108,109]$. F. nucleatum prevails in esophageal squamous cell carcinoma (ESCC), compared to adjacent non-tumour tissues, and the higher level of bacterial DNA is significantly associated with cancer-specific survival. High levels of intratumoural F. nucleatum are significant for predicting a poor survival rate in patients with ESCC and correlate with a poor response to chemotherapy $[110,111]$. F. nucleatum subsp. polymorphum is the most abundant species in oral squamous cell carcinoma (OSCC) tissues, and the numerical strength of oral Fusobacteria increases significantly with the progression of OSCC $[112,113]$.

The serum levels of IgA and IgG Abs against F. nucleatum in CRC patients are significantly higher than in healthy controls and are associated with the amount of bacterial DNA in tissues. The diagnostic potential of Abs was demonstrated in CRC; however, an association with the CRC risk was not confirmed for antibody responses to the F. nucleatum proteins [114-116]. Circulating plasma IgG and salivary IgA Abs against F. nucleatum as beneficial biomarkers in pancreatic tumour lesions are worthy of attention [117].

The tumour infiltration with $\mathrm{T}$ lymphocytes is an independent informative prognostic factor, which has been confirmed in a systematic review and meta-analysis of patients with CRC, but the role of tumour-infiltrating B cells and plasma cells remains controversial $[118,119]$. The tumour microbiome can favourably shape immune responses by increasing the density of CD3+ and CD8+ T cells and the number of Granzyme B+ cells in patients with long-term survival [71]. In contrast, colonisation of harmful bacteria, such as F. nucleatum, suppresses the $\mathrm{T}$ cell response, and the amount of bacteria is inversely associated with the density of CD3+ T cells in tumours [92,120]. Thus, in the study of the antitumour response of $\mathrm{T}$ cells in the microenvironment, an analysis of the bacteria composition is required because the targets of the immune response in tumour tissues may be of microbial origin, and some bacteria can suppress the response or decrease the density of T cells.

P. gingivalis belongs to the phylum Bacteroidetes and is an anaerobic Gram-negative pathogenic bacterium. P. gingivalis is regarded as a keystone pathogen in chronic periodontitis, causing both dysbiosis and dysregulated immune response. $P$. gingivalis has either a local effect in its native territory, the oral cavity, or a systemic effect in distant organs. The most important virulence factors are lipopolysaccharide (LPS), fimbriae, gingipains, and outer membrane vesicles. Current knowledge suggests the involvement of $P$. gingivalis in the aetiology of orodigestive cancer, and it may be a periodontitis-irrespective microbial marker for the risk of orodigestive cancer death [121,122].

The invasion of $P$. gingivalis in host cells may occur before or after malignant transformation of cells. Notwithstanding, the pathogen is present in significantly higher amounts in gingival carcinoma specimens than in normal gingival tissue [121]. Like Fusobacterium, this pathogen can survive and persist within cancer cells, causing their increased prolif- 
eration and tumour growth in vivo $[123,124]$. Intracellular antigens of $P$. gingivalis have been detected in biopsies from OSCC [125]. P. gingivalis can adhere and intracellularly invade colon cancer cells, promoting their gingipain-mediated proliferation through the activation of the kinase signalling pathway (MAPK/ERK) [124]. This pathogen is capable of disordering the host immune response through endopeptidase gingipain-mediated cleavage of IgG Abs and evading the host adaptive immune system by inhibiting IL-2 accumulation [126,127]. P. gingivalis can inhibit phagocytosis of the OSCC cell line by macrophages and induce the polarisation of macrophages into an M2 tumour-associated phenotype [128]. There is evidence that peptidoglycan of $P$. gingivalis is responsible for upregulation of the immune-regulatory receptor PD-L1 in human oral carcinoma cells, and thus may support evasion of oral carcinomas from the immune response [129].

$P$. gingivalis can promote the formation of distant metastases and chemical resistance to anticancer agents through induced inflammation [121,130], and the localisation of this bacterium in tumour tissues has been shown to be related to a poor survival rate of patients with OSCC [131]. P. gingivalis is present mainly in cancerous tissues of patients with ESCC, as has been shown using different methods. Infection was significantly related to poor differentiation, severe lymph node metastasis, and stage of ESCC, and inversely related to the overall survival rate. These observations suggest that $P$. gingivalis could be an etiologic agent and potential prognostic indicator of ESCC [132].

IgG and IgA Abs against $P$. gingivalis in the serum were found to be potential diagnostic and prognostic biomarkers for ESCC. The high serum levels of these Abs were significantly associated with worse prognosis of ESCC patients [133]. The higher serum level of IgG against $P$.gingivalis has tended to be associated overall with increased orodigestive cancer mortality $(\mathrm{P}$ trend $=0.06)[122]$. A large European prospective cohort study showed a two-fold higher risk of pancreatic cancer in individuals with a high level of plasma IgG Abs against $P$. gingivalis. On the contrary, a cluster with overall higher levels of Abs against commensal (non-pathogenic) oral bacteria showed a $45 \%$ lower risk of pancreatic cancer [134].

A comprehensive analysis of the tumour microbiome in numerous tumours and their adjacent normal tissues across seven cancer types found that each tumour type has a distinct microbiome composition. Intracellular-active bacteria are present in both cancer and immune cells (CD45+). Moreover, the DNA of various bacteria was detected in solid tumours that have no direct connection with the external environment, taking into account measures to reduce the effect of external DNA contaminants on samples [49].

Considering the ability of bacteria to preferentially colonise tumour tissues and persist in tumour cells, the question arises of how the presence of bacteria and their adhesins can affect the results of a comparative assessment of TAG expression by immunochemical methods using TAG-specific monoclonal Abs. The question should be addressed to the expression of TF and other glycans that can cross-react with bacterial glycans or serve as receptors for adhesins $[52,53,63,98]$.

Thus, dysbiosis and the intratumoural colonisation of opportunistic and pathogenic bacteria affect tumour development through complex relationships within the triad: tumour microenvironment-resident bacteria-immune response. A significant part of the humoral immune response comprises Abs against glycoconjugates of bacteria inhabiting the oral cavity and gastrointestinal tract. Alterations in the composition of serum glycoconjugates occur in cancer, and are related to the inflammatory responses and extracellular matrix remodelling accompanying cancer development [12]. Colonisation of tumours by pathogens appears to contribute significantly to these alterations.

\section{Prospects and Challenges of Integrative Glycome and Microbiome Research}

In recent years, various glycomic databases and tools have been generated [135]. Databases are available on glycan-binding proteins and glycan-mediated host-pathogen interactions. The Carbohydrate Structure DataBase http:/ / csdb.glycoscience.ru/database/ (accessed on 19 January 2021) contains the structures of glycans and glycoconjugates of 
bacteria, archaea, plants, and fungi. However, to date, integrated resources covering knowledge of the interaction of glycans and Abs have not been created. Microarrays based on synthetic carbohydrates that are inherent in human and microbial glycans for the determination of natural Abs and a humoral immune response against pathogens have been presented $[4,35,136]$. As was examined in Section 6.2 , the determination of circulating $\operatorname{IgG}$ and IgA Abs against pathogens is worthy of attention as potential diagnostic and prognostic biomarkers for orodigestive cancer. The limited accuracy of diagnosis and prognosis in immunoassays may be due to the use of heterogeneous bacterial antigens and the crossreactivity of immunodominant regions in different species. Some IgG-reactive glycan structures may be present in human pathogenic and nonpathogenic bacteria [137]. Using synthetic analogues and their combinations may improve the accuracy in the determination of Abs against pathogens, but, to date, the glycan structures of many human pathogens remain unexplored.

Innovations in high-throughput technology have prompted the development of computational and statistical analysis of accumulated bioinformatics to address the complexity of the adaptive immune repertoire and better understand the dynamics of adaptive immunity in different diseases, including cancer [138]. The microarrays with several hundred glycans may facilitate the selection of AG Abs related to tumour-colonising bacteria and contribute to a better understanding of their role in cancer pathogenesis. Further, $16 \mathrm{~S}$ rRNA gene amplicon analyses and PCR are used for the identification of bacteria and the study of microbial composition and diversity. The culture-independent method of next-generation sequencing (NGS) has tremendously simplified 16S rRNA gene sequencing to providing comprehensive data [139]. Using NGS to determine tumour-associated microbiota, together with the study of AG Abs profiling and immune response, can elucidate the role of microbiota and AG Abs in cancer pathogenesis and provide clinically relevant bioinformatics [73].

\section{Concluding Remarks}

The high-throughput profiling assay for AG Abs, together with microbiota analysis using NGS techniques, can contribute to the development of new non-invasive biomarkers for diagnosis, prognosis, screening, and proper treatment of cancer. However, the identification of universal microbial markers is difficult due to the complexity and high variability of the microbiota composition between individuals [89]. The complex network of multifactorial interactions in cancer, the molecular heterogeneity of tumours, and the individual profile of AG Abs and the microbiome are challenges for population studies and can generate many speculations. Dynamic studies on the relationship between the humoral immune response and the microbiota composition in patients, stratified by tumour pathology, appear to be more relevant for further clinical use (Figure 2). The molecular heterogeneity of malignant tumours, including genomic instability, mutations, and profile of glycosylation, largely predetermines their further development and spread, as well as overcoming the body's defence mechanisms and the response to therapy $[12,140,141]$. Commensal microorganisms maintain immune homeostasis and tolerance and can modulate the response to anticancer therapy [74]. Glycomic and microbiome research provide valuable information, but both are in need of unification and analysis that are oriented towards clinical alignment. The computational outputs based on the "multiomics" databases can provide unified bioinformation for monitoring and timely appropriate treatment, and open new opportunities for personalised oncology. 


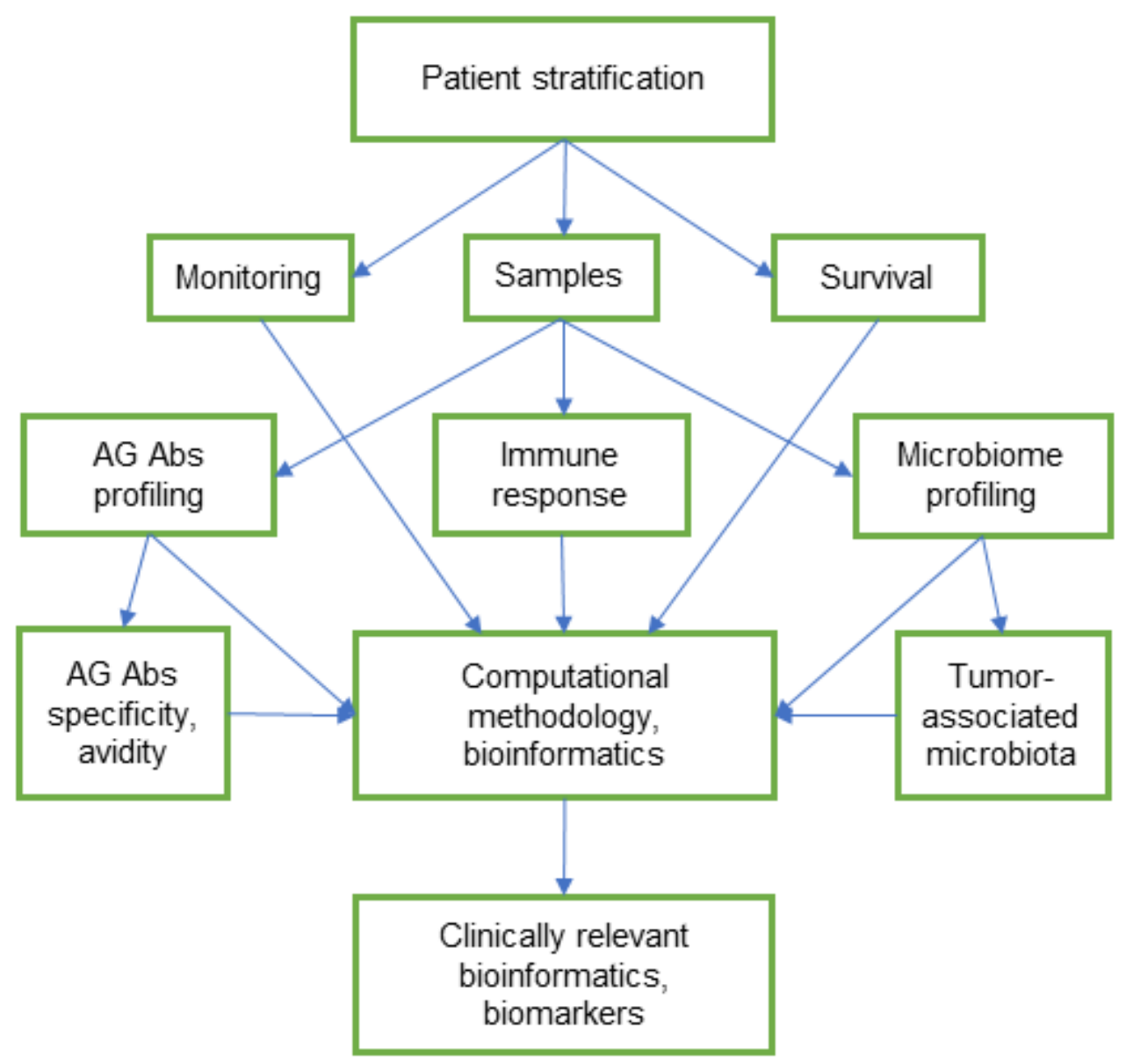

Figure 2. Conceptual scheme of integrative and clinically relevant studies of AG Abs and microbiome in cancer. Patient stratification by tumour localisation and histology, genomic mutations (tissue and liquid biopsies), and response to treatment (chemo/radiotherapy, immunotherapy, and targeted therapy). Monitoring by tumour markers (CEA, CA 19-9, CA 72-4, M2-PK), liquid biopsy, and commonly used clinical parameters. Survival: overall and cancer-specific survival. Samples: serum, plasma, and saliva for the AG Abs profiling; tumour tissues, saliva, and faeces for the microbiome profiling; tumour tissue and blood to assess the immune response. AG Abs profiling: using the glycan microarrays, differentiation of auto-AG Abs and Abs against microbiota. AG Abs specificity and avidity: affinity chromatography, surface plasmon resonance, modified and competitive ELISA. Microbiota profiling by $16 \mathrm{~S}$ rRNA gene amplicon analyses and PCR. Tumour-associated microbiota: the recognition of beneficial species and pathogens. Immune response: the association with survival of the local immune response (tumour-infiltrating lymphocytes, macrophages, and neutrophils) and systemic response (a count and ratio of immune cells).

Funding: This work received no external funding.

Acknowledgments: The author thanks Matthew Copley for correction of the English language.

Conflicts of Interest: The author declares no conflict of interest.

\section{References}

1. Varki, A. Biological roles of glycans. Glycobiology 2017, 27, 3-49. [CrossRef] [PubMed]

2. Thomas, D.; Rathinavel, A.K.; Radhakrishnan, P. Altered glycosylation in cancer: A promising target for biomarkers and therapeutics. Biochim. Biophys. Acta Rev. Cancer. 2021, 1875, 188464. [CrossRef] [PubMed]

3. $\quad$ Luetscher, R.N.D.; McKitrick, T.R.; Gao, C.; Mehta, A.Y.; McQuillan, A.M.; Kardish, R.; Boligan, K.F.; Song, X.; Lu, L.; HeimburgMolinaro, J.; et al. Unique repertoire of anti-carbohydrate antibodies in individual human serum. Sci. Rep. 2020, 10, 15436. [CrossRef] [PubMed] 
4. Huflejt, M.E.; Vuskovic, M.; Vasiliu, D.; Xu, H.; Obukhova, P.; Shilova, N.; Tuzikov, A.; Galanina, O.; Arun, B.; Lu, K.; et al. Anti-carbohydrate antibodies of normal sera: Findings, surprises and challenges. Mol. Immunol. 2009, 46, 3037-3049. [CrossRef]

5. Springer, G.F.; Desai, P.R.; Ghazizadeh, M.; Tegtmeyer, H. T/Tn pancarcinoma autoantigens: Fundamental, diagnostic, and prognostic aspects. Cancer Detect. Prev. 1995, 19, 173-182.

6. Springer, G.F. Immunoreactive T and Tn epitopes in cancer diagnosis, prognosis, and immunotherapy. J. Mol. Med. 1997, 75, 594-602. [CrossRef]

7. Fu, C.; Zhao, H.; Wang, Y.; Cai, H.; Xiao, Y.; Zeng, Y.; Chen, H. Tumor-associated antigens: Tn antigen, sTn antigen, and T antigen. HLA 2016, 88, 275-286. [CrossRef]

8. Kurtenkov, O. Profiling of naturally occurring antibodies to the Thomsen-Friedenreich antigen in health and cancer: The diversity and clinical potential. Biomed. Res. Int. 2020, 23, 9747040. [CrossRef]

9. Friedenreich, V. Production of a specific receptor quality in red cell corpuscules by bacterial activity. In The Thomsen Haemagglutination Phenomenon; Levin and Munksgaard: Copenhagen, Denmark, 1930; pp. 12-16.

10. Springer, G.F. T and Tn, general carcinoma autoantigens. Science 1984, 224, 1198-1206. [CrossRef]

11. Springer, G.F.; Desai, P.R. Tn epitopes, immunoreactive with ordinary anti-Tn antibodies, on normal, desialylated human erythrocytes and on Thomsen-Friedenreich antigen isolated therefrom. Mol. Immunol. 1985, 22, 1303-1310. [CrossRef]

12. Fernandes, E.; Sores, J.; Cotton, S.; Peixoto, A.; Ferreira, D.; Freitas, R.; Reis, C.A.; Santos, L.L.; Ferreira, J.A. Esophageal, gastric and colorectal cancers: Looking beyond classical serological biomarkers towards glycoproteomics-assisted precision oncology. Theranostics 2020, 31, 4903-4928. [CrossRef]

13. Kirwan, A.; Utratna, M.; O’Dwyer, M.E.; Joshi, L.; Kilcoyne, M. Glycosylation-based serum biomarkers for cancer diagnostics and prognostics. Biomed. Res. Int. 2015, 2015, 490531. [CrossRef]

14. Silsirivanit, A. Glycosylation markers in cancer. Adv. Clin. Chem. 2019, 89, 189-213.

15. Kailemia, M.J.; Park, D.; Lebrilla, C.B. Glycans and glycoproteins as specific biomarkers for cancer. Anal. Bioanal. Chem. 2017, 409, 395-410. [CrossRef]

16. Blsakova, A.; Kveton, F.; Kasak, P.; Tkac, J. Antibodies against aberrant glycans as cancer biomarkers. Expert Rev. Mol. Diagn. 2019, 19, 1057-1068. [CrossRef]

17. Tikhonov, A.; Smoldovskaya, O.; Feyzkhanova, G.; Kushlinskii, N.; Rubina, A. Glycan-specific antibodies as potential cancer biomarkers: A focus on microarray applications. Clin. Chem. Lab. Med. 2020, 58, 1611-1622. [CrossRef]

18. Purohit, S.; Ferris, D.G.; Alvarez, M.; Tran, P.M.H.; Tran, L.K.H.; Mysona, D.P.; Hopkins, D.; Zhi, W.; Dun, B.; Wallbillich, J.J.; et al. Better survival is observed in cervical cancer patients positive for specific anti-glycan antibodies and receiving brachytherapy. Gynecol. Oncol. 2020, 157, 181-187. [CrossRef]

19. Kurtenkov, O.; Klaamas, K.; Mensdorff-Pouilly, S.; Miljukhina, L.; Shljapnikova, L.; Chuzmarov, V. Humoral immune response to MUC1 and to the Thomsen-Friedenreich (TF) glycotope in patients with gastric cancer: Relation to survival. Acta Oncol. 2007, 46, 316-323. [CrossRef]

20. Smorodin, E.; Sergeyev, B.; Klaamas, K.; Chuzmarov, V.; Kurtenkov, O. The relation of the level of serum anti-TF, -Tn and -alpha-Gal IgG to survival in gastrointestinal cancer patients. Int. J. Med. Sci. 2013, 23, 1674-1682. [CrossRef]

21. Smorodin, E.P.; Kurtenkov, O.A.; Sergeyev, B.L. The level of anti-(GalNAc beta) and anti-para-Forssman disaccharide IgG antibodies in patients with gastrointestinal cancer: Relation to survival. Exp. Oncol. 2013, 35, 89-92.

22. Smorodin, E.P.; Sergeyev, B.L. The level of IgG antibodies reactive to TF, Tn and alpha-Gal polyacrylamide-glycoconjugates in breast cancer patients: Relation to survival. Exp. Oncol. 2016, 38, 117-121. [CrossRef]

23. Smorodin, E.P.; Kurtenkov, O.A.; Sergeyev, B.L.; Chuzmarov, V.I.; Afanasyev, V.P. The relation of serum anti-(GalNAc beta) and -para-Forssman disaccharide IgG levels to the progression and histological grading of gastrointestinal cancer. Exp. Oncol. 2007, 29, 61-66. [PubMed]

24. Barrow, H.; Guo, X.; Wandall, H.H.; Pedersen, J.W.; Fu, B.; Zhao, Q.; Chen, C.; Rhodes, J.M.; Yu, L.G. Serum galectin-2, -4, and -8 are greatly increased in colon and breast cancer patients and promote cancer cell adhesion to blood vascular endothelium. Clin. Cancer Res. 2011, 17, 7035-7046. [CrossRef] [PubMed]

25. Liu, Y.; Meng, H.; Xu, S.; Qi, X. Galectins for diagnosis and prognostic assessment of human diseases: An overview of metaanalyses. Med. Sci. Monit. 2020, 26, e923901. [CrossRef]

26. Hirano, K.; Matsuda, A.; Shirai, T.; Furukawa, K. Expression of LacdiNAc groups on N-glycans among human tumors is complex. Biomed. Res. Int. 2014, 2014, 981627. [CrossRef]

27. Yoneyama, T.; Tobisawa, Y.; Kaneko, T.; Kaya, T.; Hatakeyama, S.; Mori, K.; Sutoh Yoneyama, M.; Okubo, T.; Mitsuzuka, K.; Duivenvoorden, W.; et al. Clinical significance of the LacdiNAc-glycosylated prostate-specific antigen assay for prostate cancer detection. Cancer Sci. 2019, 110, 2573-2589. [CrossRef]

28. Bumba, L.; Laaf, D.; Spiwok, V.; Elling, L.; Křen, V.; Bojarová, P. Poly-N-acetyllactosamine neo-glycoproteins as Nanomolar ligands of human galectin-3: Binding kinetics and modeling. Int. J. Mol. Sci. 2018, 19, 372. [CrossRef]

29. Smorodin, E.P.; Kurtenkov, O.A.; Sergeyev, B.L.; Kodar, K.E.; Chuzmarov, V.I.; Afanasyev, V.P. Postoperative change of antiThomsen-Friedenreich and Tn IgG level: The follow-up study of gastrointestinal cancer patients. World J. Gastroenterol. 2008, 14, 4352-4358. [CrossRef]

30. Smorodin, E.P.; Kurtenkov, O.A.; Sergeyev, B.L.; Lilleorg, A.L.; Chuzmarov, V.I. Antibodies to tumor-associated carbohydrate epitopes in sera of cancer patients and blood donors. Exp. Oncol. 2001, 23, 109-113. 
31. Kong, C.; Gao, R.; Yan, X.; Huang, L.; He, J.; Li, H.; You, J.; Qin, H. Alterations in intestinal microbiota of colorectal cancer patients receiving radical surgery combined with adjuvant CapeOx therapy. Sci. China Life Sci. 2019, 62, 1178-1193. [CrossRef]

32. Smorodin, E.P.; Kurtenkov, O.A.; Sergeyev, B.L.; Lipping, A.A.; Chuzmarov, V.I.; Afanasyev, V.P. The relation of serum anti-TF, Tn and alpha-Gal IgG antibody levels to cancer progression and histopathological grading. Exp. Oncol. 2002, 24, $270-273$.

33. Springer, G.F.; Desai, P.R. Increase in anti-T titer scores of breast-carcinoma patients following mastectomy. Naturwissenschaften 1975, 62, 587. [CrossRef]

34. Smorodin, E.; Sergeyev, B.; Kurtenkov, O.; Kuznetsova, T.; Geller, J. IgG Antibodies to GlcNAc $\beta$ and asialo-GM2 (GA2) glycans as potential markers of liver damage in chronic hepatitis C and the efficacy of antiviral treatment. Dis. Markers 2018, 2018, 4639805. [CrossRef]

35. Bovin, N.; Obukhova, P.; Shilova, N.; Rapoport, E.; Popova, I.; Navakouski, M.; Unverzagt, C.; Vuskovic, M.; Huflejt, M. Repertoire of human natural anti-glycan immunoglobulins. Do we have auto-antibodies? Biochim. Biophys. Acta 2012, 1820, $1373-1382$. [CrossRef] [PubMed]

36. Jacob, F.; Goldstein, D.R.; Bovin, N.V.; Pochechueva, T.; Spengler, M.; Caduff, R.; Fink, D.; Vuskovic, M.I.; Huflejt, M.E.; Heinzelmann-Schwarz, V. Serum antiglycan antibody detection of nonmucinous ovarian cancers by using a printed glycan array. Int. J. Cancer 2012, 130, 138-146. [CrossRef]

37. Pochechueva, T.; Chinarev, A.; Schoetzau, A.; Fedier, A.; Bovin, N.V.; Hacker, N.F.; Jacob, F.; Heinzelmann-Schwarz, V. Blood plasma-derived anti-glycan antibodies to sialylated and sulfated glycans identify ovarian cancer patients. PLoS ONE 2016, 11, e0164230. [CrossRef]

38. Tuzikov, A.; Chinarev, A.; Shilova, N.; Gordeeva, E.; Galanina, O.; Ovchinnikova, T.; Schaefer, M.; Bovin, N. 40 years of glyco-polyacrylamide in glycobiology. Glycoconj. J. 2021, 38, 89-100. [CrossRef]

39. Smorodin, E.P.; Kurtenkov, O.A.; Sergeyev, B.L.; Klaamas, K.V.; Izotova, J.G. The characterization of cross-reactive antibodies to Thomsen-Friedenreich $\alpha / \beta$ and related glycan-conjugates with polyacrylamide carriers in patients with gastrointestinal cancer. J. Clin. Cell. Immunol. 2011, S5. [CrossRef]

40. Smorodin, E.P.; Kurtenkov, O.A.; Sergeyev, B.L.; Branovets, J.S.; Izotova, J.G.; Formanovsky, A.A. Specificity of serum anti-A(di) IgG antibodies from patients with gastrointestinal cancer. J. Immunoass. Immunochem. 2011, 32, 170-190. [CrossRef]

41. Smorodin, E.P.; Kurtenkov, O.A.; Sergeyev, B.L.; Pazynina, G.V.; Bovin, N.V. Specificity of human anti-carbohydrate IgG antibodies as probed with polyacrylamide-based glycoconjugates. Glycoconj. J. 2004, 20, 83-89. [CrossRef]

42. Smorodin, E.P.; Sergeyev, B.L.; Kurtenkov, O.A. The characterization of IgG antibodies to GalNAc beta-terminated glycans of gastric cancer survivors. Exp. Oncol. 2014, 36, 38-43. [PubMed]

43. Smorodin, E.P.; Kurtenkov, O.A.; Shevchuk, I.N.; Tanner, R.H. The isolation and characterization of human natural alphaGalspecific IgG antibodies applicable to the detection of alphaGal-glycosphingolipids. J. Immunoass. Immunochem. 2005, 26, 145-156. [CrossRef] [PubMed]

44. Galili, U.; Basbaum, C.B.; Shohet, S.B.; Buehler, J.; Macher, B.A. Identification of erythrocyte Gal alpha 1-3Gal glycosphingolipids with a mouse monoclonal antibody, Gal-13. J. Biol. Chem. 1987, 262, 4683-4688. [CrossRef]

45. Bhatia, R.; Gautam, S.K.; Cannon, A.; Thompson, C.; Hall, B.R.; Aithal, A.; Banerjee, K.; Jain, M.; Solheim, J.C.; Kumar, S.; et al. Cancer-associated mucins: Role in immune modulation and metastasis. Cancer Metastasis Rev. 2019, 38, 223-236. [CrossRef] [PubMed]

46. Lomax-Browne, H.J.; Robertson, C.; Antonopoulos, A.; Leathem, A.J.C.; Haslam, S.M.; Dell, A.; Dwek, M.V. Serum IgA1 shows increased levels of $\alpha 2,6$-linked sialic acid in breast cancer. Interface Focus 2019, 9, 20180079. [CrossRef]

47. Welinder, C.; Baldetorp, B.; Blixt, O.; Grabau, D.; Jansson, B. Primary breast cancer tumours contain high amounts of IgA1 immunoglobulin: An immunohistochemical analysis of a possible carrier of the tumour-associated Tn antigen. PLoS ONE 2013, 8, e61749. [CrossRef]

48. Zlocowski, N.; Grupe, V.; Garay, Y.C.; Nores, G.A.; Lardone, R.D.; Irazoqui, F.J. Purified human anti-Tn and anti-T antibodies specifically recognize carcinoma tissues. Sci. Rep. 2019, 9, 8097. [CrossRef]

49. Nejman, D.; Livyatan, I.; Fuks, G.; Gavert, N.; Zwang, Y.; Geller, L.T.; Rotter-Maskowitz, A.; Weiser, R.; Mallel, G.; Gigi, E.; et al. The human tumor microbiome is composed of tumor type-specific intracellular bacteria. Science 2020, 368, 973-980. [CrossRef]

50. Kappler, K.; Hennet, T. Emergence and significance of carbohydrate-specific antibodies. Genes Immun. 2020, 21, 224-239. [CrossRef]

51. Brockhausen, I. Crossroads between bacterial and mammalian glycosyltransferases. Front. Immunol. 2014, 5, 492. [CrossRef]

52. Cisar, J.O.; Sandberg, A.L.; Abeygunawardana, C.; Reddy, G.P.; Bush, C.A. Lectin recognition of host-like saccharide motifs in streptococcal cell wall polysaccharides. Glycobiology 1995, 5, 655-662. [CrossRef]

53. Yoshida, Y.; Yang, J.; Peaker, P.E.; Kato, H.; Bush, C.A.; Cisar, J.O. Molecular and antigenic characterization of a Streptococcus oralis coaggregation receptor polysaccharide by carbohydrate engineering in Streptococcus gordonii. J. Biol. Chem. 2008, 283, 12654-12664. [CrossRef]

54. Springer, G.F.; Tegtmeyer, H. Origin of anti-Thomsen-Friedenreich (T) and Tn agglutinins in man and in White Leghorn chicks. Br. J. Haematol. 1981, 47, 453-460. [CrossRef]

55. Dobrochaeva, K.; Khasbiullina, N.; Shilova, N.; Antipova, N.; Obukhova, P.; Ovchinnikova, T.; Galanina, O.; Blixt, O.; Kunz, H.; Filatov, A.; et al. Specificity of human natural antibodies referred to as anti-Tn. Mol. Immunol. 2020, 120, 74-82. 
56. Henderson, G.; Ulsemer, P.; Schöber, U.; Löffler, A.; Alpert, C.A.; Zimmermann-Kordmann, M.; Reutter, W.; Karsten, U.; Goletz, S.; Blaut, M. Occurrence of the human tumor-specific antigen structure Gal $\beta 1-3 \mathrm{GalNAc} \alpha$ - (Thomsen-Friedenreich) and related structures on gut bacteria: Prevalence, immunochemical analysis and structural confirmation. Glycobiology 2011, 21, 1277-1289. [CrossRef]

57. Ulsemer, P.; Henderson, G.; Toutounian, K.; Löffler, A.; Schmidt, J.; Karsten, U.; Blaut, M.; Goletz, S. Specific humoral immune response to the Thomsen-Friedenreich tumor antigen (CD176) in mice after vaccination with the commensal bacterium Bacteroides ovatus D-6. Cancer Immunol. Immunother. 2013, 62, 875-887. [CrossRef]

58. Ulsemer, P.; Toutounian, K.; Kressel, G.; Goletz, C.; Schmidt, J.; Karsten, U.; Hahn, A.; Goletz, S. Impact of oral consumption of heat-treated Bacteroides xylanisolvens DSM 23964 on the level of natural TF $\alpha$-specific antibodies in human adults. Benef. Microbes 2016, 7, 485-500. [CrossRef]

59. Cooke, C.L.; An, H.J.; Kim, J.; Canfield, D.R.; Torres, J.; Lebrilla, C.B.; Solnick, J.V. Modification of gastric mucin oligosaccharide expression in rhesus macaques after infection with Helicobacter pylori. Gastroenterology 2009, 137, 1061-1071.e8. [CrossRef]

60. Klaamas, K.; Kurtenkov, O.; Rittenhouse-Olson, K.; Brjalin, V.; Miljukhina, L.; Shljapnikova, L.; Engstrand, L. Expression of tumor-associated Thomsen-Friedenreich antigen $(\mathrm{T} \mathrm{Ag})$ in Helicobacter pylori and modulation of $\mathrm{T}$ Ag specific immune response in infected individuals. Immunol. Investig. 2002, 31, 191-204. [CrossRef]

61. Li, G.; Yu, S.; Xu, J.; Zhang, X.; Ye, J.; Wang, Z.; He, Y. The prognostic role of Helicobacter pylori in gastric cancer patients: A meta-analysis. Clin. Res. Hepatol. Gastroenterol. 2019, 43, 216-224. [CrossRef]

62. Coats, M.T.; Murphy, T.; Paton, J.C.; Gray, B.; Briles, D.E. Exposure of Thomsen-Friedenreich antigen in Streptococcus pneumoniae infection is dependent on pneumococcal neuraminidase A. Microb. Pathog. 2011, 50, 343-349. [CrossRef] [PubMed]

63. Abed, J.; Emgård, J.E.; Zamir, G.; Faroja, M.; Almogy, G.; Grenov, A.; Sol, A.; Naor, R.; Pikarsky, E.; Atlan, K.A.; et al. Fap2 mediates Fusobacterium nucleatum colorectal adenocarcinoma enrichment by binding to tumor-expressed Gal-GalNAc. Cell Host Microbe 2016, 20, 215-225. [CrossRef] [PubMed]

64. Conover, M.S.; Ruer, S.; Taganna, J.; Kalas, V.; De Greve, H.; Pinkner, J.S.; Dodson, K.W.; Remaut, H.; Hultgren, S.J. Inflammationinduced adhesin-receptor interaction provides a fitness advantage to uropathogenic E. coli during chronic infection. Cell Host Microbe 2016, 20, 482-492. [CrossRef] [PubMed]

65. Schneider, C.; Smith, D.F.; Cummings, R.D.; Boligan, K.F.; Hamilton, R.G.; Bochner, B.S.; Miescher, S.; Simon, H.U.; Pashov, A.; Vassilev, T.; et al. The human IgG anti-carbohydrate repertoire exhibits a universal architecture and contains specificity for microbial attachment sites. Sci. Transl. Med. 2015, 7, 269ra1. [CrossRef]

66. Huai, G.; Qi, P.; Yang, H.; Wang, Y. Characteristics of $\alpha$-Gal epitope, anti-Gal antibody, $\alpha 1,3$ galactosyltransferase and its clinical exploitation (Review). Int. J. Mol. Med. 2016, 37, 11-20. [CrossRef]

67. Galili, U.; Clark, M.R.; Shohet, S.B.; Buehler, J.; Macher, B.A. Evolutionary relationship between the natural anti-Gal antibody and the Gal alpha 1-3Gal epitope in primates. Proc. Natl. Acad. Sci. USA 1987, 84, 1369-1373. [CrossRef]

68. Bernth Jensen, J.M.; Petersen, M.S.; Ellerman-Eriksen, S.; Møller, B.K.; Jensenius, J.C.; Sørensen, U.B.S.; Thiel, S. Abundant human anti-Gal $\alpha 3$ Gal antibodies display broad pathogen reactivity. Sci. Rep. 2020, 10, 4611. [CrossRef]

69. Galili, U.; Mandrell, R.E.; Hamadeh, R.M.; Shohet, S.B.; Griffiss, J.M. Interaction between human natural anti-alpha-galactosyl immunoglobulin $\mathrm{G}$ and bacteria of the human flora. Infect. Immun. 1988, 56, 1730-1737. [CrossRef]

70. Bernth Jensen, J.M.; Skeldal, S.; Petersen, M.S.; Møller, B.K.; Hoffmann, S.; Jensenius, J.C.; Skov Sørensen, U.B.; Thiel, S. The human natural anti- $\alpha \mathrm{Gal}$ antibody targets common pathogens by broad-spectrum polyreactivity. Immunology 2021, 162, 434-451. [CrossRef]

71. Riquelme, E.; Zhang, Y.; Zhang, L.; Montiel, M.; Zoltan, M.; Dong, W.; Quesada, P.; Sahin, I.; Chandra, V.; San Lucas, A.; et al. Tumor microbiome diversity and composition influence pancreatic cancer outcomes. Cell 2019, 178, 795-806.e12. [CrossRef]

72. Cremonesi, E.; Governa, V.; Garzon, J.F.G.; Mele, V.; Amicarella, F.; Muraro, M.G.; Trella, E.; Galati-Fournier, V.; Oertli, D.; Däster, S.R.; et al. Gut microbiota modulate T cell trafficking into human colorectal cancer. Gut 2018, 67, 1984-1994. [CrossRef]

73. Rodriguez, R.M.; Khadka, V.S.; Menor, M.; Hernandez, B.Y.; Deng, Y. Tissue-associated microbial detection in cancer using human sequencing data. BMC Bioinform. 2020, 21, 523. [CrossRef]

74. Buchta Rosean, C.; Feng, T.Y.; Azar, F.N.; Rutkowski, M.R. Impact of the microbiome on cancer progression and response to anti-cancer therapies. Adv. Cancer Res. 2019, 143, 255-294.

75. Choudhry, H. The microbiome and its implications in cancer immunotherapy. Molecules 2021, 26, 206. [CrossRef]

76. Francescone, R.; Hou, V.; Grivennikov, S.I. Microbiome, inflammation, and cancer. Cancer J. 2014, 20, 181-189. [CrossRef]

77. Ge, Y.; Wang, X.; Guo, Y.; Yan, J.; Abuduwaili, A.; Aximujiang, K.; Yan, J.; Wu, M. Gut microbiota influence tumor development and Alter interactions with the human immune system. J. Exp. Clin. Cancer Res. 2021, 40, 42. [CrossRef]

78. Drago, L. Probiotics and colon cancer. Microorganisms 2019, 7, 66. [CrossRef]

79. Gao, Z.; Guo, B.; Gao, R.; Zhu, Q.; Wu, W.; Qin, H. Probiotics modify human intestinal mucosa-associated microbiota in patients with colorectal cancer. Mol. Med. Rep. 2015, 12, 6119-6127. [CrossRef]

80. Longhi, G.; van Sinderen, D.; Ventura, M.; Turroni, F. Microbiota and cancer: The emerging beneficial role of bifidobacteria in cancer immunotherapy. Front. Microbiol. 2020, 11, 575072. [CrossRef]

81. Chowdhury, A.H.; Adiamah, A.; Kushairi, A.; Varadhan, K.K.; Krznaric, Z.; Kulkarni, A.D.; Neal, K.R.; Lobo, D.N. Perioperative probiotics or synbiotics in adults undergoing elective abdominal surgery: A systematic review and meta-analysis of randomized controlled trials. Ann. Surg. 2020, 271, 1036-1047. [CrossRef] 
82. Amitay, E.L.; Carr, P.R.; Gies, A.; Laetsch, D.C.; Brenner, H. Probiotic/synbiotic treatment and postoperative complications in colorectal cancer patients: Systematic review and meta-analysis of randomized controlled trials. Clin. Transl. Gastroenterol. 2020, 11, e00268. [CrossRef] [PubMed]

83. Balachandran, V.P.; Łuksza, M.; Zhao, J.N.; Makarov, V.; Moral, J.A.; Remark, R.; Herbst, B.; Askan, G.; Bhanot, U.; Senbabaoglu, Y.; et al. Identification of unique neoantigen qualities in long-term survivors of pancreatic cancer. Nature 2017, 551, 512-516. [CrossRef] [PubMed]

84. Oliva, M.; Mulet-Margalef, N.; Ochoa-De-Olza, M.; Napoli, S.; Mas, J.; Laquente, B.; Alemany, L.; Duell, E.J.; Nuciforo, P.; Moreno, V. Tumor-associated microbiome: Where do we stand? Int. J. Mol. Sci. 2021, 22, 1446. [CrossRef] [PubMed]

85. Huang, X.; Pan, J.; Xu, F.; Shao, B.; Wang, Y.; Guo, X.; Zhou, S. Bacteria-based cancer immunotherapy. Adv. Sci. 2021, 8, 2003572. [CrossRef]

86. Gupta, H.; Youn, G.S.; Shin, M.J.; Suk, K.T. Role of gut microbiota in hepatocarcinogenesis. Microorganisms 2019, 7, 121. [CrossRef]

87. Dapito, D.H.; Mencin, A.; Gwak, G.Y.; Pradere, J.P.; Jang, M.K.; Mederacke, I.; Caviglia, J.M.; Khiabanian, H.; Adeyemi, A.; Bataller, R.; et al. Promotion of hepatocellular carcinoma by the intestinal microbiota and TLR4. Cancer Cell 2012, 21, 504-516. [CrossRef]

88. Elsalem, L.; Jum'ah, A.A.; Alfaqih, M.A.; Aloudat, O. The bacterial microbiota of gastrointestinal cancers: Role in cancer pathogenesis and therapeutic perspectives. Clin. Exp. Gastroenterol. 2020, 13, 151-185. [CrossRef]

89. Villéger, R.; Lopès, A.; Veziant, J.; Gagnière, J.; Barnich, N.; Billard, E.; Boucher, D.; Bonnet, M. Microbial markers in colorectal cancer detection and/or prognosis. World J. Gastroenterol. 2018, 24, 2327-2347. [CrossRef]

90. Sun, J.; Tang, Q.; Yu, S.; Xie, M.; Xie, Y.; Chen, G.; Chen, L. Role of the oral microbiota in cancer evolution and progression. Cancer Med. 2020, 9, 6306-6321. [CrossRef]

91. Li, Q.; Hu, Y.; Zhou, X.; Liu, S.; Han, Q.; Cheng, L. Role of oral bacteria in the development of oral squamous cell carcinoma. Cancers 2020, 12, 2797. [CrossRef]

92. Nosho, K.; Sukawa, Y.; Adachi, Y.; Ito, M.; Mitsuhashi, K.; Kurihara, H.; Kanno, S.; Yamamoto, I.; Ishigami, K.; Igarashi, H.; et al. Association of Fusobacterium nucleatum with immunity and molecular alterations in colorectal cancer. World J. Gastroenterol. 2016, 22, 557-566. [CrossRef]

93. Hashemi Goradel, N.; Heidarzadeh, S.; Jahangiri, S.; Farhood, B.; Mortezaee, K.; Khanlarkhani, N.; Negahdari, B. Fusobacterium nucleatum and colorectal cancer: A mechanistic overview. J. Cell. Physiol. 2019, 234, 2337-2344. [CrossRef]

94. Lee, J.A.; Yoo, S.Y.; Oh, H.J.; Jeong, S.; Cho, N.Y.; Kang, G.H.; Kim, J.H. Differential immune microenvironmental features of microsatellite-unstable colorectal cancers according to Fusobacterium nucleatum status. Cancer Immunol. Immunother. 2021, 70, 47-59. [CrossRef]

95. Bullman, S.; Pedamallu, C.S.; Sicinska, E.; Clancy, T.E.; Zhang, X.; Cai, D.; Neuberg, D.; Huang, K.; Guevara, F.; Nelson, T.; et al. Analysis of Fusobacterium persistence and antibiotic response in colorectal cancer. Science 2017, 358, 1443-1448. [CrossRef]

96. Riley, D.R.; Sieber, K.B.; Robinson, K.M.; White, J.R.; Ganesan, A.; Nourbakhsh, S.; Dunning Hotopp, J.C. Bacteria-human somatic cell lateral gene transfer is enriched in cancer samples. PLoS Comput. Biol. 2013, 9, e1003107. [CrossRef]

97. Gur, C.; Ibrahim, Y.; Isaacson, B.; Yamin, R.; Abed, J.; Gamliel, M.; Enk, J.; Bar-On, Y.; Stanietsky-Kaynan, N.; Coppenhagen-Glazer, S.; et al. Binding of the Fap2 protein of Fusobacterium nucleatum to human inhibitory receptor TIGIT protects tumors from immune cell attack. Immunity 2015, 42, 344-355. [CrossRef]

98. Parhi, L.; Alon-Maimon, T.; Sol, A.; Nejman, D.; Shhadeh, A.; Fainsod-Levi, T.; Yajuk, O.; Isaacson, B.; Abed, J.; Maalouf, N.; et al. Breast cancer colonization by Fusobacterium nucleatum accelerates tumor growth and metastatic progression. Nat. Commun. 2020, 11, 3259. [CrossRef]

99. Gur, C.; Maalouf, N.; Shhadeh, A.; Berhani, O.; Singer, B.B.; Bachrach, G.; Mandelboim, O. Fusobacterium nucleatum supresses anti-tumor immunity by activating CEACAM1. Oncoimmunology 2019, 8, e1581531. [CrossRef]

100. Kaplan, C.W.; Ma, X.; Paranjpe, A.; Jewett, A.; Lux, R.; Kinder-Haake, S.; Shi, W. Fusobacterium nucleatum outer membrane proteins Fap2 and RadD induce cell death in human lymphocytes. Infect. Immun. 2010, 78, 4773-4778. [CrossRef]

101. Chen, T.; Li, Q.; Wu, J.; Wu, Y.; Peng, W.; Li, H.; Wang, J.; Tang, X.; Peng, Y.; Fu, X. Fusobacterium nucleatum promotes M2 polarization of macrophages in the microenvironment of colorectal tumours via a TLR4-dependent mechanism. Cancer Immunol. Immunother. 2018, 67, 1635-1646. [CrossRef] [PubMed]

102. Wu, J.; Li, Q.; Fu, X. Fusobacterium nucleatum contributes to the carcinogenesis of colorectal cancer by inducing inflammation and suppressing host immunity. Transl. Oncol. 2019, 12, 846-851. [CrossRef] [PubMed]

103. Mima, K.; Nishihara, R.; Qian, Z.R.; Cao, Y.; Sukawa, Y.; Nowak, J.A.; Yang, J.; Dou, R.; Masugi, Y.; Song, M.; et al. Fusobacterium nucleatum in colorectal carcinoma tissue and patient prognosis. Gut 2016, 65, 1973-1980. [CrossRef]

104. Leung, P.H.M.; Subramanya, R.; Mou, Q.; Lee, K.T.; Islam, F.; Gopalan, V.; Lu, C.T.; Lam, A.K. Characterization of mucosaassociated microbiota in matched cancer and non-neoplastic mucosa from patients with colorectal cancer. Front. Microbiol. 2019, 10, 1317. [CrossRef] [PubMed]

105. Huangfu, S.C.; Zhang, W.B.; Zhang, H.R.; Li, Y.; Zhang, Y.R.; Nie, J.L.; Chu, X.D.; Chen, C.S.; Jiang, H.P.; Pan, J.H. Clinicopathological and prognostic significance of Fusobacterium nucleatum infection in colorectal cancer: A meta-analysis. J. Cancer 2021, 12, 1583-1591. [CrossRef]

106. Boehm, E.T.; Thon, C.; Kupcinskas, J.; Steponaitiene, R.; Skieceviciene, J.; Canbay, A.; Malfertheiner, P.; Link, A. Fusobacterium nucleatum is associated with worse prognosis in Lauren's diffuse type gastric cancer patients. Sci. Rep. 2020, 10, 16240. [CrossRef] 
107. Mitsuhashi, K.; Nosho, K.; Sukawa, Y.; Matsunaga, Y.; Ito, M.; Kurihara, H.; Kanno, S.; Igarashi, H.; Naito, T.; Adachi, Y.; et al. Association of Fusobacterium species in pancreatic cancer tissues with molecular features and prognosis. Oncotarget 2015, 6, 7209-7220. [CrossRef]

108. Pushalkar, S.; Hundeyin, M.; Daley, D.; Zambirinis, C.P.; Kurz, E.; Mishra, A.; Mohan, N.; Aykut, B.; Usyk, M.; Torres, L.E.; et al. The pancreatic cancer microbiome promotes oncogenesis by induction of innate and adaptive immune suppression. Cancer Discov. 2018, 8, 403-416. [CrossRef]

109. Zhang, W.; Zhang, K.; Zhang, P.; Zheng, J.; Min, C.; Li, X. Research progress of pancreas-related microorganisms and pancreatic cancer. Front. Oncol. 2021, 10, 604531. [CrossRef]

110. Yamamura, K.; Baba, Y.; Nakagawa, S.; Mima, K.; Miyake, K.; Nakamura, K.; Sawayama, H.; Kinoshita, K.; Ishimoto, T.; Iwatsuki, M.; et al. Human microbiome Fusobacterium nucleatum in esophageal cancer tissue is associated with prognosis. Clin. Cancer Res. 2016, 22, 5574-5581. [CrossRef]

111. Yamamura, K.; Izumi, D.; Kandimalla, R.; Sonohara, F.; Baba, Y.; Yoshida, N.; Kodera, Y.; Baba, H.; Goel, A. Intratumoral Fusobacterium nucleatum levels predict therapeutic response to neoadjuvant chemotherapy in esophageal squamous cell carcinoma. Clin. Cancer Res. 2019, 25, 6170-6179. [CrossRef]

112. Al-Hebshi, N.N.; Nasher, A.T.; Maryoud, M.Y.; Homeida, H.E.; Chen, T.; Idris, A.M.; Johnson, N.W. Inflammatory bacteriome featuring Fusobacterium nucleatum and Pseudomonas aeruginosa identified in association with oral squamous cell carcinoma. Sci. Rep. 2017, 7, 1834. [CrossRef] [PubMed]

113. Yang, C.Y.; Yeh, Y.M.; Yu, H.Y.; Chin, C.Y.; Hsu, C.W.; Liu, H.; Huang, P.J.; Hu, S.N.; Liao, C.T.; Chang, K.P.; et al. Oral microbiota community dynamics associated with oral squamous cell carcinoma staging. Front. Microbiol. 2018, 9, 862. [CrossRef]

114. Kurt, M.; Yumuk, Z. Diagnostic accuracy of Fusobacterium nucleatum IgA and IgG ELISA test in colorectal cancer. Sci. Rep. 2021, 11, 1608. [CrossRef]

115. Wang, H.F.; Li, L.F.; Guo, S.H.; Zeng, Q.Y.; Ning, F.; Liu, W.L.; Zhang, G. Evaluation of antibody level against Fusobacterium nucleatum in the serological diagnosis of colorectal cancer. Sci. Rep. 2016, 6, 33440. [CrossRef]

116. Butt, J.; Jenab, M.; Pawlita, M.; Overvad, K.; Tjonneland, A.; Olsen, A.; Boutron-Ruault, M.C.; Carbonnel, F.; Mancini, F.R.; Kaaks, R.; et al. Antibody responses to Fusobacterium nucleatum proteins in prediagnostic blood samples are not associated with risk of developing colorectal cancer. Cancer Epidemiol. Biomark. Prev. 2019, 28, 1552-1555. [CrossRef]

117. Alkharaan, H.; Lu, L.; Gabarrini, G.; Halimi, A.; Ateeb, Z.; Sobkowiak, M.J.; Davanian, H.; Fernández Moro, C.; Jansson, L.; Del Chiaro, M.; et al. Circulating and salivary antibodies to Fusobacterium nucleatum are associated with cystic pancreatic neoplasm malignancy. Front. Immunol. 2020, 11, 2003. [CrossRef]

118. Idos, G.E.; Kwok, J.; Bonthala, N.; Kysh, L.; Gruber, S.B.; Qu, C. The prognostic implications of tumor infiltrating lymphocytes in colorectal cancer: A systematic review and meta-analysis. Sci. Rep. 2020, 10, 3360. [CrossRef]

119. Wouters, M.C.A.; Nelson, B.H. Prognostic significance of tumor-infiltrating B cells and plasma cells in human cancer. Clin. Cancer Res. 2018, 24, 6125-6135. [CrossRef]

120. Mima, K.; Sukawa, Y.; Nishihara, R.; Qian, Z.R.; Yamauchi, M.; Inamura, K.; Kim, S.A.; Masuda, A.; Nowak, J.A.; Nosho, K.; et al. Fusobacterium nucleatum and T cells in colorectal carcinoma. JAMA Oncol. 2015, 1, 653-661. [CrossRef]

121. Olsen, I.; Yilmaz, Ö. Possible role of Porphyromonas gingivalis in orodigestive cancers. J. Oral Microbiol. 2019, 11, 1563410. [CrossRef]

122. Ahn, J.; Segers, S.; Hayes, R.B. Periodontal disease, Porphyromonas gingivalis serum antibody levels and orodigestive cancer mortality. Carcinogenesis 2012, 33, 1055-1058. [CrossRef] [PubMed]

123. Gnanasekaran, J.; Binder Gallimidi, A.; Saba, E.; Pandi, K.; Eli Berchoer, L.; Hermano, E.; Angabo, S.; Makkawi, H.A.; Khashan, A.; Daoud, A.; et al. Intracellular Porphyromonas gingivalis promotes the tumorigenic behavior of pancreatic carcinoma cells. Cancers 2020, 12, 2331. [CrossRef] [PubMed]

124. Mu, W.; Jia, Y.; Chen, X.; Li, H.; Wang, Z.; Cheng, B. Intracellular Porphyromonas gingivalis promotes the proliferation of colorectal cancer cells via the MAPK/ERK signaling pathway. Front. Cell. Infect. Microbiol. 2020, 10, 584798. [CrossRef] [PubMed]

125. Sztukowska, M.N.; Ojo, A.; Ahmed, S.; Carenbauer, A.L.; Wang, Q.; Shumway, B.; Jenkinson, H.F.; Wang, H.; Darling, D.S.; Lamont, R.J. Porphyromonas gingivalis initiates a mesenchymal-like transition through ZEB1 in gingival epithelial cells. Cell. Microbiol. 2016, 18, 844-858. [CrossRef]

126. Vincents, B.; Guentsch, A.; Kostolowska, D.; von Pawel-Rammingen, U.; Eick, S.; Potempa, J.; Abrahamson, M. Cleavage of IgG1 and IgG3 by gingipain $\mathrm{K}$ from Porphyromonas gingivalis may compromise host defense in progressive periodontitis. FASEB J. 2011, 25, 3741-3750. [CrossRef]

127. Khalaf, H.; Bengtsson, T. Altered T-cell responses by the periodontal pathogen Porphyromonas gingivalis. PLoS ONE 2012, 7, e45192. [CrossRef]

128. Liu, S.; Zhou, X.; Peng, X.; Li, M.; Ren, B.; Cheng, G.; Cheng, L. Porphyromonas gingivalis promotes immunoevasion of oral cancer by protecting cancer from macrophage attack. J. Immunol. 2020, 205, 282-289. [CrossRef]

129. Groeger, S.; Denter, F.; Lochnit, G.; Schmitz, M.L.; Meyle, J. Porphyromonas gingivalis cell wall components induce programmed death ligand 1 (PD-L1) expression on human oral carcinoma cells by a receptor-interacting protein kinase 2 (RIP2)-dependent mechanism. Infect. Immun. 2020, 88, e00051-20. [CrossRef]

130. Song, J.M.; Woo, B.H.; Lee, J.H.; Yoon, S.; Cho, Y.; Kim, Y.D.; Park, H.R. Oral administration of Porphyromonas gingivalis, a major pathogen of chronic periodontitis, promotes resistance to paclitaxel in mouse xenografts of oral squamous cell carcinoma. Int. J. Mol. Sci. 2019, 20, 2494. [CrossRef] 
131. Wen, L.; Mu, W.; Lu, H.; Wang, X.; Fang, J.; Jia, Y.; Li, Q.; Wang, D.; Wen, S.; Guo, J.; et al. Porphyromonas gingivalis promotes oral squamous cell carcinoma progression in an immune microenvironment. J. Dent. Res. 2020, 99, 666-675. [CrossRef]

132. Gao, S.; Li, S.; Ma, Z.; Liang, S.; Shan, T.; Zhang, M.; Zhu, X.; Zhang, P.; Liu, G.; Zhou, F.; et al. Presence of Porphyromonas gingivalis in esophagus and its association with the clinicopathological characteristics and survival in patients with esophageal cancer. Infect. Agent. Cancer 2016, 11, 3. [CrossRef]

133. Gao, S.G.; Yang, J.Q.; Ma, Z.K.; Yuan, X.; Zhao, C.; Wang, G.C.; Wei, H.; Feng, X.S.; Qi, Y.J. Preoperative serum immunoglobulin $\mathrm{G}$ and $\mathrm{A}$ antibodies to Porphyromonas gingivalis are potential serum biomarkers for the diagnosis and prognosis of esophageal squamous cell carcinoma. BMC Cancer 2018, 18, 17. [CrossRef]

134. Michaud, D.S.; Izard, J.; Wilhelm-Benartzi, C.S.; You, D.H.; Grote, V.A.; Tjønneland, A.; Dahm, C.C.; Overvad, K.; Jenab, M.; Fedirko, V.; et al. Plasma antibodies to oral bacteria and risk of pancreatic cancer in a large European prospective cohort study. Gut 2013, 62, 1764-1770. [CrossRef]

135. Li, X.; Xu, Z.; Hong, X.; Zhang, Y.; Zou, X. Databases and bioinformatic tools for glycobiology and glycoproteomics. Int. J. Mol. Sci. 2020, 21, 6727. [CrossRef]

136. Geissner, A.; Reinhardt, A.; Rademacher, C.; Johannssen, T.; Monteiro, J.; Lepenies, B.; Thépaut, M.; Fieschi, F.; Mrázková, J.; Wimmerova, M.; et al. Microbe-focused glycan array screening platform. Proc. Natl. Acad. Sci. USA 2019, 116, 1958-1967. [CrossRef]

137. Von Gunten, S.; Smith, D.F.; Cummings, R.D.; Riedel, S.; Miescher, S.; Schaub, A.; Hamilton, R.G.; Bochner, B.S. Intravenous immunoglobulin contains a broad repertoire of anticarbohydrate antibodies that is not restricted to the IgG2 subclass. J. Allergy Clin. Immunol. 2009, 123, 1268-1276.e15. [CrossRef] [PubMed]

138. Miho, E.; Yermanos, A.; Weber, C.R.; Berger, C.T.; Reddy, S.T.; Greiff, V. Computational strategies for dissecting the highdimensional complexity of adaptive immune repertoires. Front. Immunol. 2018, 9, 224. [CrossRef]

139. Sanschagrin, S.; Yergeau, E. Next-generation sequencing of $16 \mathrm{~S}$ ribosomal RNA gene amplicons. J. Vis. Exp. 2014, 90, 51709. [CrossRef]

140. Molinari, C.; Marisi, G.; Passardi, A.; Matteucci, L.; De Maio, G.; Ulivi, P. Heterogeneity in colorectal cancer: A challenge for personalized medicine? Int. J. Mol. Sci. 2018, 19, 3733. [CrossRef]

141. Peixoto, A.; Relvas-Santos, M.; Azevedo, R.; Santos, L.L.; Ferreira, J.A. Protein glycosylation and tumor microenvironment alterations driving cancer hallmarks. Front. Oncol. 2019, 9, 380. [CrossRef] 